\title{
The Strategy of Football Normalization and Institutionalization in Colleges
}

\author{
Quan Xu and Xuanjie Zhou \\ NanChang Institute of Science \& Technology, Nanchang,330108
}

\begin{abstract}
Keywords: Campus football; System; Normalization; Institutionalization
\end{abstract}
\begin{abstract}
Football with its passion, teamwork and other characteristics as a long history of sports, since its introduction to China, has been the majority of people's favorite, especially in football sports development and football training practice, the formation of football experience and the specific practice connect with China's national conditions of football culture. With wide promotion of the campus football, its problems are increasingly prominent, so it is urgent to take appropriate measures to resolve them. Based on the campus football perspective, how to make campus football normalization, institutionalization and sustainable development, is the most difficult and most urgent problem. From the development and development problems of campus football to analyze the factors that affect the development of campus football, to explore the strategy for the current campus football activities, can be more targeted to carry out the effective implementation of campus football to promote development of campus football effectively.
\end{abstract}

\section{Introduction}

The development of campus football in China can be traced back to FIFA's "Touch the world" slogan, the slogan is proposed by FIFA in grassroots football plan. It emphasizes that any teenager interested in football, no matter they are men and women, have the right to get systematic football training and the opportunity to participate in football matches. The purpose is to make the football game everywhere, so that everyone can participate in the football equally, and football is no longer away from people, but to develop into a fair, interesting and simple sport event. More people can contact with football, through the football game to communicate and fully enjoy the fun of football, so it also is called grassroots football plan. And China's campus football is a Chinese characteristics of a grass-roots football movement. The development of football in China is inseparable from the development of campus football, the development of campus football for our football has provided a reserve force, but also conducive to the formation of campus football culture. This article mainly carried out in-depth study on the campus football culture construction, in order to better promote the development of campus football.

\section{The Problems of Campus Football Promotion Process}

First, the lack of awareness of the campus football activities. The top-level design of the country's football activities on campus is far-sighted, but there is a disagreement about specific practitioners schools, students and parents. For the parents of the students, they are concerned about the child get injured in the football training and confrontation, worried about the child participate in football activities too much and delay the study of cultural classes, for schools, is also facing the increase in school enrollment, weakening physical education, staying in the difficult status of paying attention to campus football activities, and training young football reserve talents. Due to lack of awareness, it will cause that the campus football is only a formality, and can not implemented well.

Second, the lack of campus football security and evaluation system. The establishment of the guarantee system is the fundamental guarantee for the sustainable development of campus football. The existing school football training venues is less, can not meet the requirements that more and more students to participate in football activities, the school curriculum arranged is unreasonable, the school in order to consider the enrollment rate and reduce the time of sports courses, having no much time to carry out football activities, the lack of incentives for students and teachers to 
participate in football activities, amateur training and competition time for physical education teachers are not included in the normal assessment indicators, the school lacks regular assessment and evaluation of policies and systems.

Third, the campus football training level is not high and the competition system is not perfect. The current level of football training on campus is not high, the campus football does not form a unified standard training system, grass-roots football sports teachers lack of awareness and attention is not high, football teachers have not been systematically trained, lack of experience of scientific training. Due to the different levels of sports infrastructure in various schools, resulting in uneven levels of school football training, they did not use a unified entry standard, the game results are not comparable, the results vary widely, the game lost practical value and did not really promote the promotion of campus football Activities.

Fourth, the basic level of campus football coach is relatively low. For a long time, China's training in coaches is not strong, resulting in situation that the level of grass-roots coaches in China is not high. And the salary of coaches is low, the number is serious shortage. With the development of campus football, the number of campus football coaches shrink the problem. Many grass-roots sports teachers are not graduated from the football professional or just work now, they lack experience, only explore the road in the teaching, the lack of appropriate scientific and effective teaching materials can not form a scientific, systematic training.

The Value of Campus Football Culture Construction Normalization .The school is the place to educate people, which naturally cannot be separated from the development of campus culture. Through different teaching ideas and teaching model to form a different campus culture. But the ultimate goal of education are the same, is to cultivate young people to get moral, intellectual, physical development. The integration of football sport into the campus culture can be a good way to promote the comprehensive development of students, both exercise of the body, but also cultivate the spirit of cooperation, hardship, but also improve the ability to respond.

Conducive to School Material and Cultural Construction. Through studying the connotation of football culture on campus in China, the campus football culture in our country is formed under the specific environment of the campus. Teachers and students form a kind of material wealth and spiritual wealth through football teaching and football competition in the campus. It can improve the understanding between teachers and students, so that teachers and students form more common language, but also build football venues in the campus, to landscape school playground. Campus football culture is a group culture forming within the school scope. It is based on the student as the main body, mainly to carry out some extracurricular football to enrich extracurricular sports activities.

Conducive to the Construction of Spiritual Culture. Football is a collective sport that requires participants to have a strong team spirit and the will of no fearing to hardship. By participating in football, adolescents can better get along with others, change self-centered habits, conducive to interpersonal harmony, besides in football game, there will be many rules, there are many unwritten code of conduct, If you do not comply with these rules, it is difficult to achieve results in football, will not be accepted by other players. Adolescents have a certain understanding of the rules through football games, and will develop the habit of compliance with the rules in life, which will benefit for them into community life to a certain degree.

\section{The Countermeasure of Normalization of football Culture Construction on Campus}

Campus football takes the "self-organization" development path, do not require campus football into chaos state and fend for themselves, but rely on educational means and market means to mobilize resources in order to solve the campus football competition and training problems, only follow the football teaching and learning rules, movement skills form to the law, the allocation of resources to carry out personnel training, teaching and training become reasonable. In addition, through the exchange of material, energy and information with the outside world, campus football is possible to achieve an ordered transition.

Deal with the Relationship of the Cultivation of Football Talent and the Overall Development well . "Combining sports and education" becoming intimate has never been like 
today in China because of football. Therefore, the campus football not only focus on improving the level of football, but also creating more complete and dynamic people, we struggle to "moral and intellectual" balanced development goals, perhaps really will be achieved in a number of years.

Deal with the Relationship between Football and other Sports Projects. The prerequisite of adolescent campus football is students to learn the basic technology and culture knowledge in the school, to promote the comprehensive development for all students, it is the internal and external school football activities that students generally benefit from them. Football activity is a highly antagonistic collective sports project, both needing fierce competition, but also needing unity and cooperation, you can hone the awareness of competition, the spirit of tenacious struggle and the character of being not afraid of difficult.

Establish a Fair Evaluation System. The long-term development of campus football must establish a long-term development of campus football system, so the establishment of long-term development of the evaluation mechanism is necessary. Long-term development depends on the system, competition system, training system and other support, hence the assessment of indicators on the long-term development of the campus football measures will help prompt the long-term development of campus football. The evaluation mechanism of campus football system should also have the characteristics such as stage development and persistence. Because the development of campus football is constantly changing, the difference between different regions is also larger, so the establishment of campus football evaluation mechanism need to consider the comprehensive factors.

\section{Summary}

In summary, the colleges actively carry out campus football sport in China, establish campus football culture, not only can enrich the school's material and cultural construction, but also can enrich the school's spiritual and cultural construction. The development of campus football cannot be achieved overnight, the campus football system is complex and changeable. At present, China's campus football in the early stage, with the characteristics of rapid development and big change, the advantage and disadvantage of the State Sports General Administration and the Ministry of Education's dual leadership exist at the same time, to clarify the framework of China's campus football system, establish campus football system normalization and institutionalization of the system, so as to has an important role in promoting the long-term development of China's campus football. We believe that even though the campus football development is still very difficult and long, but as long as we pursuit relentless, the football of our country must have a bright future.

\section{References}

[1] Zhao Y, University C N. Thoughts on the development of five- player football in colleges and universities [J]. Journal of Changchun University of Chinese Medicine, 2016.

[2] Danns. Financial education in U.S. state colleges and universities [J]. Springer Briefs in Psychology, 2016, 20(2):135-144.

[3] Zhang Q, Tourism D O, University M. Implementing experiences and reference point for the innovative and enterprising education in Taiwan colleges and universities [J]. Journal of Minjiang University, 2016.

[4] An-An X U, University H N. Reflection and Innovation of Subsidy-and-Education System in Local Normal Colleges and Universities in Internet Plus Era [J]. Teacher Education Forum, 2016.

[5] Sang Y F, Amp Z A, University F. The Education and Cultivation of Personality is the Ultimate Goal of the Cultural Construction in Colleges and Universities [J]. Journal of Hubei Correspondence University, 2016.

[6] Xu L Y. The teaching of football course in Colleges and Universities [J]. Journal of Jiamusi Education Institute, 2013. 
[7] Wang F, Sun F R, Zhang Y, et al. On the Implementation of MOOC Education in Private Colleges and Universities [J]. Journal of Hubei Correspondence University, 2016.

[8] Fan J M, University J N. The Importance of Strengthening the Aesthetic Education of Film and Television Media in Colleges and Universities [J]. Journal of Hubei Correspondence University, 2016.

[9] Peng S. The Study on Influence Factor of the Development of High-Level Football Teams in some Chinese Colleges and Universities [J]. Journal of XI an Institute of Physical Education, 1994.

[10] Siegfried J J, Sanderson A R, Mchenry P. The economic impact of colleges and universities [J]. Economics of Education Review, 2007, 26(5): 546-558.

[11]Xiang L H, Liu F J, De-Xi W U, et al. Construction of Quality Education Evaluation System in Agricultural Colleges and Universities [J]. Journal of Anhui Agricultural Sciences, 2016. 